\title{
THE COMPARISON OF SELF REGULATED LEARNING FKIP STUDENTS BY USING MACROMEDIA FLASH BASED INTERACTIVE LEARNING MEDIA
}

\author{
Yen Aryni ${ }^{1}$, Khairun $\mathrm{Nisa}^{2}$, Anim $^{3}$ \\ Fkip Universitas Asahan, Jl. Jendral Ahmad Yani Kisaran \\ Eeni_Minie19@yahoo.com ${ }^{1}$, nisakhairun2206@gmail.com ${ }^{2}$, \\ 'animfaqot30031991@gmail.com ${ }^{3}$
}

\begin{abstract}
The aim of research that the students feel less confident about their ability to finishing the task by lecturers. Thus, it can make impact to increase the self regulated learning academic behavior. Based on the result of the research, it can be concluded that the comparison of self regulated learning of FKIP University students of Asahan consisting of Indonesian and literature study program, English study program, and Mathematics study program using interactive media based on macromedia flash obtained an average of self regulated learning questionnaire score in English is in the high category of 27.13, Indonesian and literature of 25.92, mathematics of 25.75 is in the category of being. It can be concluded that learning by using interactive learning media based on macromedia flash can give a positive impact on Self Regulated Learning in FKIP Universitas Asahan.
\end{abstract}

\section{Keyword: Comparison, Self Regulated Learning, Macromedia Flash}

\section{INTRODUCTION}

The University is an unit of the higher education in advanced level as a middle education in formal education. It suitable with University, according to UU No. 20, 2003, article 19 paragraph 1. It stated that: First, The University is a middle higher included diploma program, bachelor program, magister program, speacialist and doctor. Second, The University as institution have role and the strategies position to get education achievement as macro which need repair continuently to realize the quality human resources. It is encourages the educators/lecturer must be able to make a situation creative learning inovative to be able to stimulate the spirit and self regulated students learning to get the result education.

But in reality, the survey results show that FKIP UNA students feel less confident about the ability that students have when did the tasks by lecturers, thus impact the increase in self-regulated learning academic behavior. This resulted in students often delayed to do the tasks of college. Such behavior makes the student can not reach the target of long study that has been determined.

Based on the results of interviews with five students of the Faculty of Teacher Training and Education (UNA) semester 4, the fifth student's statement is almost the same, they mentioned that there are some difficult and still boring subjects in Teacher Training and Education (UNA) a low level of confidence in the ability of each student to do the tasks given lecturers, causing students to feel lazy and become pessimistic.

A low level of confidence in the ability of each student, resulting in students prefering to postpone work and wait for their friend's report to finish and then copy, other than that the student prefers to work, then chooses to join the Student Activity Unit (SME) or organization when the activity is done during college hours, lazy to do the task immediately other than that.

Responding to problems that arise learning in college, need to find an alternative learning that can provide opportunities for students to express ideas / ideas optimally so that students become more independent. In order to reach the students' ability in faculty, so as to change towards the better, students are required to play an active role during the learning process.

In addition, it is necessary to find a learning solution that can solve all the problems faced by students. Lecturers must be able to create an atmosphere of learning that is able to explore the 
capabilities of students in solving problems by students, this is expected to be student independence so that educational goals can be achieved such as applicable law.

Learning model applied by lecturers so far is paired with the use of ICT-based learning media that will provide many facilities for students in solving learning problems. One of them with the existence of a media-based macromedia flash learning, will increase one's independence to learn, improve one's learning efficiency in managing time and place, mastering the material optimally, quickly and accurately, and introduce innovation in learning. Multimedia becomes a means that can facilitate the needs of students in learning and stimulate students' curiosity to cause self-regulated learning of these students.

According to Pintrich (1990), self-regulated learning encompasses students' metacognitive strategies for planning, monitoring, and modifying their cognition. Zimmerman and Schunk (Ghonsooly, 2011) In the world of education, self regulator skills have been found related to student achievement and motivation. This is related to the characteristics and objectives of learning mathematics. Then Zimmerman (Pintrich, 1990), self-regulated refers to the self-generated experience, feelings, and actions that are planned and adapted to the attainment of personal goals.

Based on the above background researchers interested in researching with the Target of this research conducted on students in the Faculty of Teacher Training and Education (UNA) semester 4 with the title "Comparison of Self Regulated Learning Students Using Interactive Media Based Learning Macromedia Flash at FKIP University Asahan."

\section{RESEARCH PURPOSES}

Research Objectives in this research is related to: How is the comparison of self-regulated learning of FKIP students in Indonesian language and literature education, English, and mathematics study program using macromediaflash based interactive learning media.

\section{OBJECTIVE OF THE STUDY}

Problem formulation in this research is related to: How is the comparison of self-regulated learning of FKIP students in Indonesian language and literature, English, and mathematics education programs using macromedia flash-based interactive learning media ?

\section{LITERATURE VIEW}

\section{Learning Independence}

In addition to the cognitive aspects, affective aspects are also important in learning math. Wardani (Tandililing, 2011) states that the affective aspect also takes part in the successful learning of student math; affective aspects of learning independence. According to Pintrich (1990), self-regulated learning encompasses students' metacognitive strategies for planning, monitoring, and modifying their cognition. Zimmerman and Schunk (Ghonsooly, 2011) In the field of education, self-regulatory skills have been found to be related to prestige and motivation. This is related to the characteristics and objektives of learning mathematics.

The independence of learning mathematics is a very important factor in determining the success of students in learning mathematics. Technological developments also have an impact on enriching accessible learning resources, thus supporting their learning for self-taught students (Tandililing, 2011). Zimmerman (1990) also mentions: Self regulated learning is a circle of "selforiented feedback." This cycle requires a cycle process in which students monitor the effectiveness of learning methods or strategies and react to this feedback in various ways, ranging from vague changes in self-perception to change manifest in behavior such as changing the use of learning strategies. According to Zimmerman (Latipah, 2010) Self regulated learning emphasizes the importance of personal responsibility and controls the knowledge and skills acquired. Furthermore, according to Qohar and Utari (2013) states that Self-Regulated Learning is not a mental ability or academic skills such as reading ability but as a self-directed process transformed into a certain mental ability. According to Zimmerman \& Schunk (Kitsantas, 2008) states that From a social cognitive perspective, 
self-regulation involves: (a) setting specific goals; (b) utilizing tasks such as elaborating, organizing, and practicing; (c) displaying a high degree of self-efficacy and basic interest; and (d) self-monitoring and reflecting on performance outcomes.

The positive influence of Self-Regulated Learning is to form a character that has motivation to learn throughout life (life long learning) and also become independent in various other life contexts. In addition, according to Zimmerman and Schunk 2001 research that self regulation learning will bring the achievement of success in the learning process. Similarly, previous studies suggest that even if a person has a good level of intelligence, personality, home environment, and school environment, but without the ability of self regulation, the student will not be able to achieve optimal academic achievement (Nahariani, 2012). Sumarmo suggests learning independence is a careful design process and selfmonitoring of the cognitive and affective processes in completing an academic task. Furthermore, Sumarmo specifies indicators of learning independence as follows: 1) learning initiatives, 2) diagnose learning needs, 3) set learning goals and objectives, 4) monitor, organize and control learning progress, 5) view difficulty as a challenge, 6) utilize and seek relevant sources, 7) selecting and applying learning, 8) evaluating process and learning outcomes, and 9) owning self-concept (Sugandi and Utari, 2010). The learning independence of the students referred to in this study is limited to five indicators: 1) learning initiatives 2) setting targets and learning objectives 3) monitoring, managing and controlling learning progress 4) utilizing and locating relevant sources and 5) evaluating processes and outcomes learn.

\section{MACROMEDIA FLASH}

Programmers have always had something to say about the design of the applications they code, and designers have always leveraged their technical knowledge to ensure that their designs are supported by appropriate functionality. As the interactive industry matures, more and more products require high-end multimedia development. There are times when programmers write code and creativity generate assets and the boundary between them is clear. Programmers always have something to say about the design of their coded applications, and designers always utilize their technical knowledge to make their designs are supported by the appropriate functionality. As the interactive industry matures, more and more products that require high-end multimedia development. Clear examples include video games, DVDs, media websites, and even tools, such as Tivos with the increased skills needed to be developed. This product includes both technical and creative skills. The list of tools often used by designers to create interactive applications includes;

1. PhotoShop

2. Ilustrator

3. DeBabelizer

4. Maya

5. 3DSMax

6. Flash

\section{FLASH 8}

Flash 8 is the latest version of the Flash authoring tool, and the Flash 8 Player is the latest version of the player used to run Flash applications. Flash 8 introduces many improvements to the authoring tool, as well as to the player. This book focuses on the new features in Flash 8 that are related to Action Script coding. Since Flash 8 can be used to develop applications for earlier versions of the Flash Player, making use of these new code features is optional. When Flash-8-specific code is used, it will only run correctly in the Flash 8 player. When relevant, this is noted in the example code.

\section{TIMELINES, LAYERS,THE STAGE, MOVIECLIPS, AND THE LIBRARY}

\section{Timelines}

One of the most important concepts in Flash development is the timeline. In every new Flash document, the "Main Timeline" is the most prominent feature in the workspace. Figure 2.1 Shows a new, empty Flash document with the Main Timeline at the top of the workspace. 


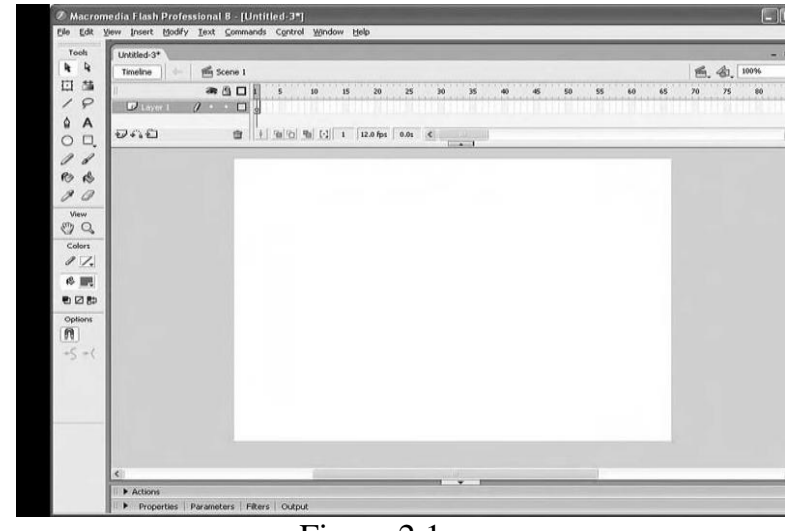

Figure 2.1

The Main Timeline is made up of a sequence of "frames" which are numbered sequentially. There is an unlimited supply of frames. The scroll bar at the bottom of the Timeline pane is used to navigate through all the frames in the timeline. In a new Flash document, all of the frames are completely empty except for one. The first frame on the first layer contains an empty "keyframe". A keyframe is a container that can hold a media element, a label, a script, or all three. In order to put anything on a timeline frame, it must have a keyframe created on it first. New, empty keyframes are created using Insert-_Timeline-_Key frame (also_SHIFT_F6_).

\section{Symbol Timelines}

Each "Symbol" in a Flash document also has a timeline. New Symbols are created by choosing Insert-_New Symbol. Figure 2.2 shows the "Create New Symbol" dialog.

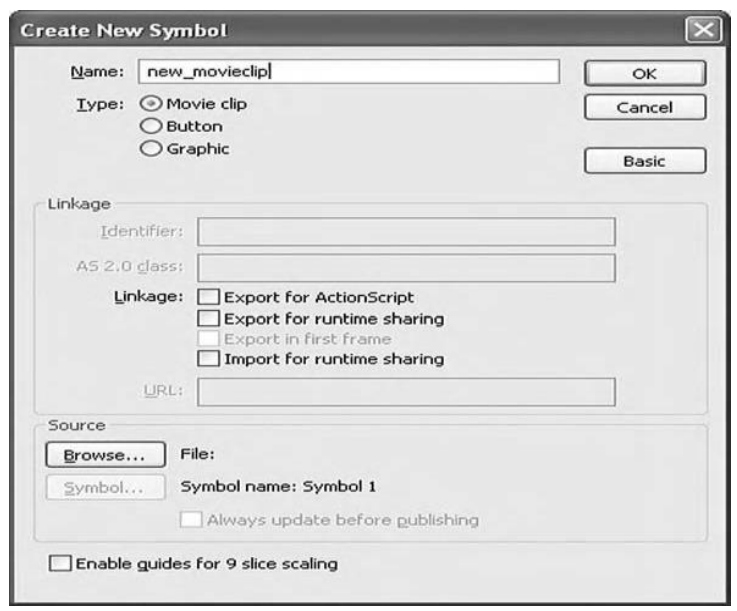

Figure 2.2

Every new symbol needs to have a unique name, specified in the "Name:" field. Each symbol also has a type, which can be either: "Movie clip", "Button", or "Graphic". Each of these symbol types has its own timeline. Figure 2.3 shows the timeline for a new MovieClip symbol. The new MovieClip is named "new_movieclip". In the bar just above the new symbol's timeline is a MovieClip icon with the name of the new MovieClip, "new_movieclip". This indicates that the timeline of "new_movieclip" is currently active and being edited in the workspace. Flash came into existence as a tool for creating animations, so Flash timelines are an abstraction of the "filmstrip". The frames in a Flash timeline are analogous to the frames in a movie filmstrip. 


\section{Layers}

Every frame in a timeline exists on a "Layer". Timelines can have many Layers of frames. Layers are a common feature in many graphical design applications including PhotoShop, Illustrator, etc. In Flash, as in many other applications, layers are used to establish which graphical elements are displayed on top of others. Layers also determine the order in which timeline scripts are executed. Visual elements on the first layer are displayed on top of visual elements on the second layer, etc. Scripts on the first layer are executed before scripts on the second layer, etc. The "Layers.fla" file in the ch2 folder of the Examples shows an example of how layers can be used to determine which symbols are drawn on top of others. The first thing to notice in Layers.fla is that there are four layers named: "ship", "powerups", "space debris", and "space bg". The "space bg" layer contains the bitmap image of the space scene. As it is the bottom-most layer, all of the other elements are drawn on top of it. The next thing to notice is that each layer has one keyframe, and the keyframe is displayed with a black dot in it. This indicates that the keyframe is not empty and that it has a media element on it.

\section{Scenes}

Scenes are yet another way to group elements of a Flash application. Every new Flash document includes one Scene, called "Scene 1". Flash applications can have many Scenes, and for some types of projects they are very useful. Dynamic applications, like the game in this book, rarely need more than one Scene, so they are not discussed in detail. In a nutshell, having multiple Scenes is like have multiple Flash documents in one. This was a very valuable feature in the early days before it was possible to dynamically load external SWF files. In recent version of Flash, most of the benefits of Scenes can be achieved using coding techniques.

\section{Stage}

Of course, the most noticeable thing about Layers.fla is the Stage: it contains a space scene. The stage is where everything on the Main Timeline is displayed. In this example, the Stage contains a background image (on the "space bg" layer), a "crystal" symbol and a generic "debris" symbol (on the "space debris" layer), two "powerup" symbols (on the "powerups" layer), and a "ship" (on the "ship" layer). When a symbol is selected (clicked on), its layer is also selected, the "crystal" symbol is selected. As a result, it has a blue selection box around it and the "space debris" layer is highlighted. Also, the properties of the crystal symbol are displayed in the Properties panel at the bottom of the workspace. The properties listed for the crystal indicate that it is:

1. a MovieClip symbol,

2. an instance of the "crystal" symbol,

3. "Instance Name" is "crystal1",

4. located at coordinates $(29.8,119.3)$,

5. 50 pixels wide and 52.9 pixels high.

\section{METHODOLOGY}

The research method used in this research is experiment with $2 \times 2$ factorial design. The sample in this research is semseter IV (four) students of Indonesian language and literature education, English education, and Mathematics Education of Teacher Training and Education Faculty of Asahan University. The research instrument used in this research is a questionnaire that contains the results obtained by the students during the lecture by using flash media macro learning media as much as 30 questions. 


\section{RESULT AND DISCUSSION}

The research results obtained as follows:

\begin{tabular}{clc}
\hline No. & \multicolumn{1}{c}{ Name } & Score \\
\hline $\mathbf{1}$ & Amaylia Dessy Wijaya & 30 \\
$\mathbf{2}$ & Vefi Sukanti & 30 \\
$\mathbf{3}$ & Elviani Sinaga & 29 \\
$\mathbf{4}$ & Riska Ayu Putri & 29 \\
$\mathbf{5}$ & Siti Nurhalimah & 28 \\
$\mathbf{6}$ & Sinta Sri Andriani & 28 \\
$\mathbf{7}$ & Suriani & 28 \\
$\mathbf{8}$ & Eva Sriyanti & 28 \\
$\mathbf{9}$ & Nurhaliza Lubis & 28 \\
$\mathbf{1 0}$ & Heri Agus Niawan & 28 \\
$\mathbf{1 1}$ & Nadya Ifroh Siahaan & 27 \\
$\mathbf{1 2}$ & Supriadi & 27 \\
$\mathbf{1 3}$ & Sri Dewi Astuti & 27 \\
$\mathbf{1 4}$ & Diana Astuti & 26 \\
$\mathbf{1 5}$ & Maysaroh Lubis & 25 \\
$\mathbf{1 6}$ & Ilhamsyah Putra & 24 \\
$\mathbf{1 7}$ & Tengku Jihan Humairoh & 24 \\
$\mathbf{1 8}$ & Ramlatul Jannah & 23 \\
$\mathbf{1 9}$ & Dhea Morika & 23 \\
$\mathbf{2 0}$ & Siti Laili & 23 \\
$\mathbf{2 1}$ & Rahmadhani & 23 \\
$\mathbf{2 2}$ & Intan Permadani & 22 \\
$\mathbf{2 3}$ & Nazla Rahmatika Almughnin & 22 \\
$\mathbf{2 4}$ & Rafina Azhara & 20 \\
\hline & Total & 622 \\
\hline & & Table l: Data of Indonesianand
\end{tabular}

Table 1 : Data of Indonesian and Literature study program

Based on the above questionnaire scores, it is known that the distribution of scores obtained by students as follows:

\begin{tabular}{lll}
\hline No. & Nama & Score \\
\hline $\mathbf{1}$ & Dwi Ramania Putri & 29 \\
$\mathbf{2}$ & M. Agum Dirga Siregar & 29 \\
$\mathbf{3}$ & Suci Aprilia & 29 \\
$\mathbf{4}$ & Rike Diana Putri & 29 \\
$\mathbf{5}$ & Maya Anggi Syahfitry Siregar & 29 \\
$\mathbf{6}$ & Chika Dewi Lumban Tobing & 28 \\
$\mathbf{7}$ & Syahfitri & 28 \\
$\mathbf{8}$ & Miftahul Jannah & 28 \\
$\mathbf{9}$ & Indah Nurjanah & 28 \\
$\mathbf{1 0}$ & Rizka Indriani & 28 \\
$\mathbf{1 1}$ & Asniati & 28 \\
$\mathbf{1 2}$ & Yasha Sonia & 28 \\
$\mathbf{1 3}$ & Gandis Rindiani Putrandi & 27 \\
$\mathbf{1 4}$ & Deo Fandy Mahendra Ritonga & 27 \\
$\mathbf{1 5}$ & Elisabeth Natalia Marpaung & 27 \\
$\mathbf{1 6}$ & Jeklin Indah Sari Silalahi & 27 \\
$\mathbf{1 7}$ & Astuti Halawa & 27 \\
$\mathbf{1 8}$ & Kamisah & 27 \\
$\mathbf{1 9}$ & Rafika Sarah & 26 \\
$\mathbf{2 0}$ & Dea Melinda & 26 \\
\hline
\end{tabular}




\begin{tabular}{lll}
\hline $\mathbf{2 1}$ & Anisa Sapitri & 26 \\
$\mathbf{2 2}$ & Lala Afni Maranatha Tarigan & 25 \\
$\mathbf{2 3}$ & Weni Indah Sari & 23 \\
$\mathbf{2 4}$ & Jeni Winda Lestari & 22 \\
\hline & Total & 624 \\
\hline
\end{tabular}

Table 2 : Data of English study program

\begin{tabular}{|c|c|c|}
\hline No. & Nama & Score \\
\hline 1 & Windi Meirani & 29 \\
\hline 2 & Rahmawati & 29 \\
\hline 3 & Nurhapni Anggita Pohan & 28 \\
\hline 4 & Fransiska Octapiyani Putri & 28 \\
\hline 5 & Noveri & 28 \\
\hline 6 & Siti Khadijah & 28 \\
\hline 7 & Umi Kalsum & 27 \\
\hline 8 & Putra Panjaitan & 27 \\
\hline 9 & Monica Oktavia Chaniago & 27 \\
\hline 10 & Sri Wahyun Tambuse & 27 \\
\hline 11 & Nurhakiki Nasution & 27 \\
\hline 12 & Nurhayati & 26 \\
\hline 13 & Debby Christin Panjaitan & 26 \\
\hline 14 & Ulty Chika Putri & 26 \\
\hline 15 & Nur Atmi Ningsi & 26 \\
\hline 16 & Ajeng Nengtias Arianti & 26 \\
\hline 17 & Ninda Wahyuni & 25 \\
\hline 18 & Suci Nurjannah & 25 \\
\hline 19 & Indri Sri Rahayu & 24 \\
\hline 20 & Dita Gustantina & 24 \\
\hline 21 & Sri Wahyun Tambuse & 23 \\
\hline 22 & Mitra Pasaribu & 23 \\
\hline 23 & Yovi Syarah Harahap & 22 \\
\hline 24 & Irna Sari & 17 \\
\hline \multicolumn{2}{|r|}{ Total } & 618 \\
\hline
\end{tabular}

Table 3 : Data of Mathematic study program

Description of Data fom students

\begin{tabular}{|c|c|c|c|}
\hline Result & $\begin{array}{c}\text { Pendidikan Bahasa dan } \\
\text { Sastra Indonesia } \\
\end{array}$ & $\begin{array}{c}\text { Pendidikan Bahasa } \\
\text { Inggris }\end{array}$ & $\begin{array}{c}\text { Pendidikan } \\
\text { Matematika }\end{array}$ \\
\hline $\mathrm{N}$ & 24 & 24 & 24 \\
\hline Total & 622 & 651 & 618 \\
\hline Mean & 25,92 & 27,13 & 25,75 \\
\hline Modus & 28 & 28 & 26 \\
\hline Median & 27 & 28 & 26 \\
\hline Varians & 8,25 & 3,24 & 7,07 \\
\hline SD & 2,87 & 1,80 & 2,66 \\
\hline Nilai Tertinggi & 30 & 29 & 29 \\
\hline Nilai Terendah & 20 & 22 & 17 \\
\hline Rentangan & 10 & 7 & 12 \\
\hline
\end{tabular}




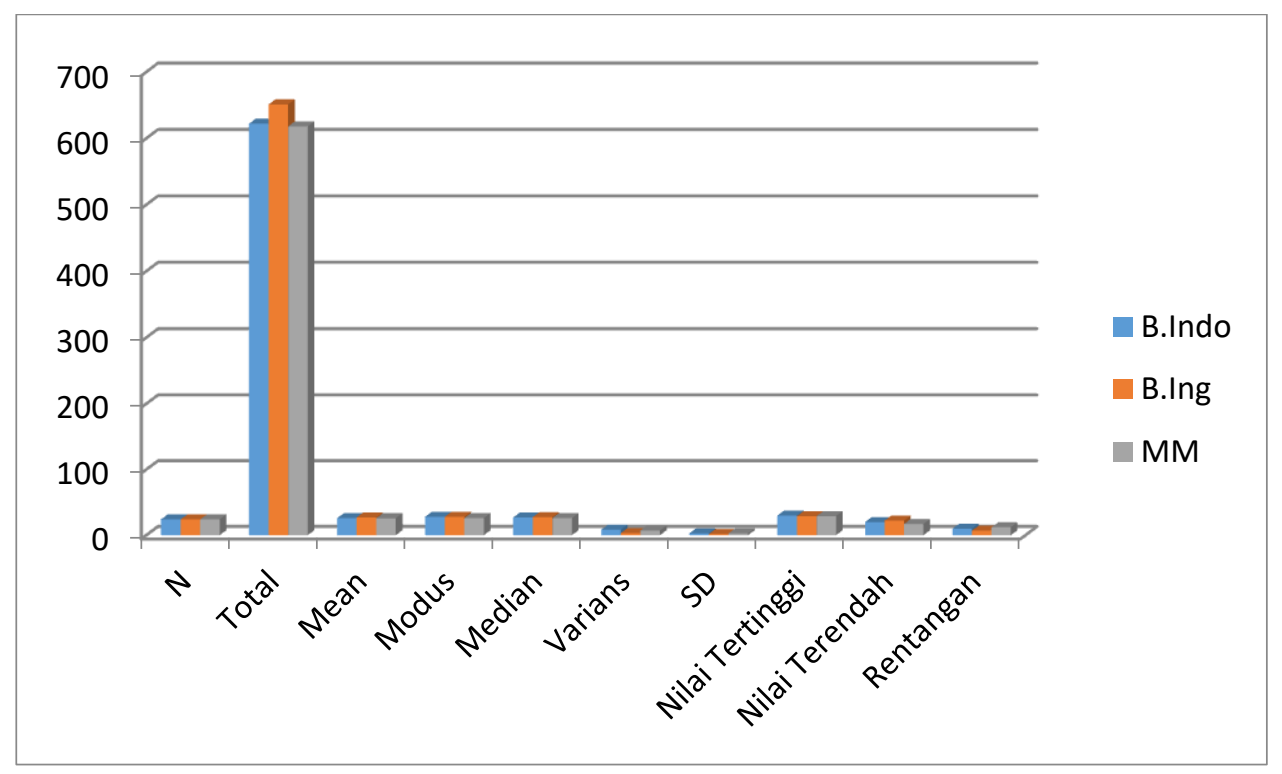

Based on the results of three questionnaire scores obtained it can be concluded that the total value of the three subjects seen that for the field of English education course is superior to the average value of 27.13 and for the educational average of 25.92 Indonesian, and 25 mathematics education, 75 . This shows that Self Regulated Learning in English education students is in the high category and for Indonesian language education and Mathematics education is in the category of sendang.

\section{CONCLUSION}

Based on the result of the research, it can be concluded that the comparison of self regulated learning of FKIP University students of Asahan consisting of the prodipenddikan Indonesian language and literature, English education, and mathematics education using interactive learning media based on macromediaflash obtained by the average self-regulated learning questionnaire in English education in the high category of 27.13, Indonesian language education and literature of 25.92, mathematics education of 25.75 is in the category of being. It can be concluded that learning by using interactive learning media based on macromedia flash can give a positive impact on Self Regulated Learning in FKIP Universitas Asahan .

\section{REFERENCES}

Latipah, E. 2010.Strategi Self- Regulated Learning dan Prestasi Belajar: Kajian Meta Analisis. Jurnal Psikologi. Vol. 37. No.1 Juni 2010: 110-129. Universitas Negeri Sunan Kalijaga. Fakultas tarbiyah.

Michael, Andrew Rapo Alex.2006. Understanding Macromedia Flash 8 Action Script 2 Basic Tecnique for Creatives, Burlington

Pintrich, Paul R., dan Elisabeth V.D.G. 1990. Motivational and Self-regulated Learning Components of Classroom Academic Performance.Journal of Educational Psychology. Copyright by the American Psychological Association, Inc.O022-O663/90/\$00.75.

Zimmerman, B.J. (1990). Self regulated learning and academic achievement: An overview. Educational Psychologist, 25 (1), 3-17.

Tandililing, E. 2011.The Enhancement of Mathematical Communication and Self Regulated Learning of Senior High School Students Through PQ4R Strategy Accompanied by Refutation Text Reading. Yogyakarta: Proceeding. [International Seminar and the Fourth National Conference on Mathematics Education 2011 Department of Mathematics Education, Yogyakarta State University Yogyakarta, July 21-23 2011]. ISBN : 978 - 979 - 16353 - 7 - 0 